
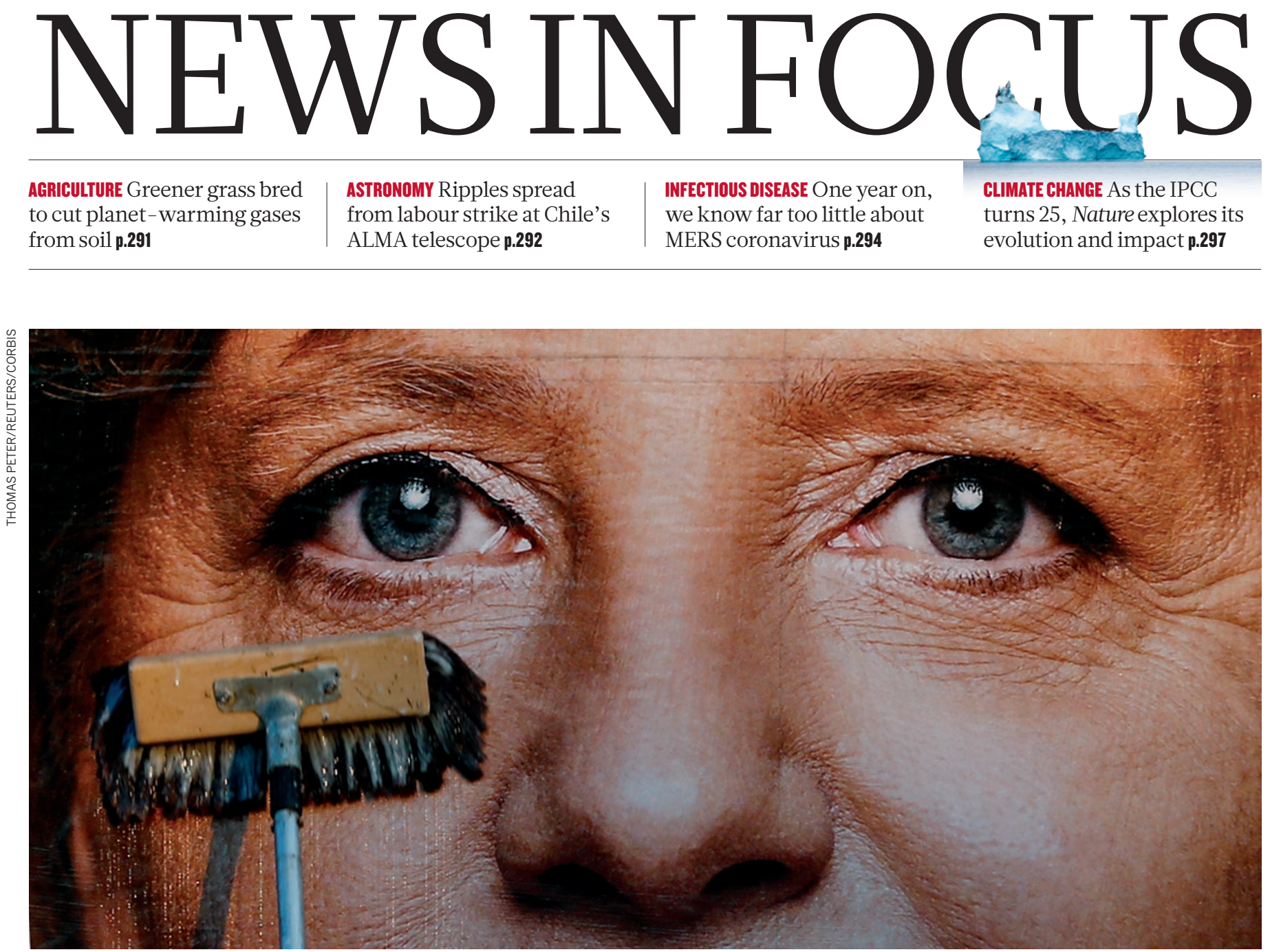

German Chancellor Angela Merkel has her eyes on a third term in office.

\title{
POLICY
}

\section{Germany hits science high}

But election prompts fears that budgetary pressures may sap strong investment.

\section{BY QUIRIN SCHIERMEIER}

A physicist by training, German Chancellor Angela Merkel has a proven affinity for science. Thanks to generous government funding, German research has thrived since she first came to power eight years ago. But as she prepares for a probable third term in office after elections on 22 September - the governing coalition between her Christian Democratic Union (CDU) party and the Free Democrats is well ahead in polls - scientists and science organizations are concerned that the years of plenty may soon be over.

On the face of it, there does not seem too much to worry about. Since 2005, the federal government's overall science spending has increased by a whopping $60 \%$ - from $€ 9$ billion (US $\$ 12$ billion) up to around $€ 14.4$ billion in
2013 (see 'The rise of German science'). By comparison, in 1995-2005, the German science budget rose by only $7.5 \%$. Industrial research has also flourished: Germany is now close to spending $3 \%$ of its gross domestic product (GDP) on science and technology, a key target of the European Union (EU) 2020 strategy for growth that only Finland, Sweden and Denmark have met so far.

These investments have paid off. This month, the World Economic Forum, based in Switzerland, moved Germany up two notches on its ranking of the world's most competitive economies, noting that heavy investment in research and development has added to Germany's strengths. It now stands at number four, behind Switzerland, Singapore and Finland.

"It's a great achievement of Merkel's chancellorship to have firmly anchored science as an important pillar of our country's wealth and innovative power," says Peter Gruss, outgoing president of the Max Planck Society, which runs 82 research institutes in Germany. But he fears that the good times may end if other budget pressures, such as debt reduction, welfare and transport, are prioritized after the election.

The German political landscape is complex. The ruling coalition's main competitors are Peer Steinbrück's left-leaning Social Democrats. But they, too, would need a coalition partner to govern. The most likely candidates are the Greens, but such junior parties often fail to win the $5 \%$ of votes needed to secure parliamentary representation, so a grand coalition of the CDU and Social Democrats cannot be ruled out.

The scientific landscape is more clear-cut. In their election programmes, all parties represented in the current parliament - including 


\section{THE RISE OF GERMAN SCIENCE}

Since 2000, German science spending has increased by about $70 \%$ and is now approaching $3 \%$ of GDP.

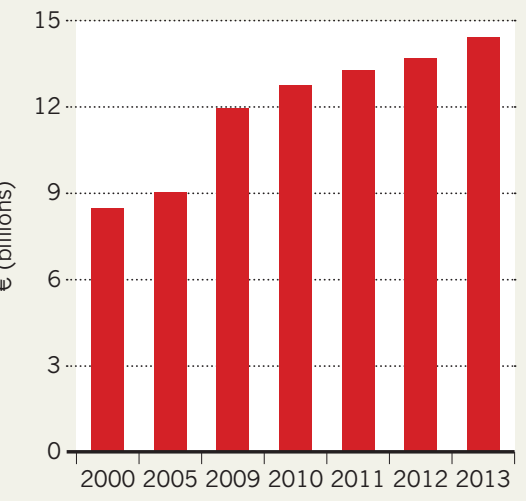

- the Greens and the Left party - have taken a decidedly pro-science stance. They all, for example, see energy research as a priority to support Germany's planned transition, known as the Energiewende, to a non-nuclear, lowcarbon system dominated by renewable energy sources (see Nature 496, 156-158; 2013). Likewise, there is cross-party agreement that health research must be strengthened and remodelled, a policy driven by Germany's rapidly ageing population (see 'Health considerations').

All parties claim that climate change is another priority, and none will axe any commitments already made on major science issues, such as Germany's decision to phase out nuclear power by 2022 .

For her part, Merkel has vowed not to "fall behind" the 3\% GDP spend on research and development. But her government, burdened by debt and aid payments to Greece and other struggling eurozone countries, has set itself tough fiscal restrictions. A 2009 constitutional amendment called the Schuldenbremse ('debt brake') means that from 2016, the federal government - and from 2020, state governments - will no longer be allowed to run deficits.

For the moment, the science boom continues. Over the past eight years, the large German science organizations - including the Max Planck Society, the Helmholtz Association of German Research Centres and the German Research Foundation (DFG), the main funder of university research - have benefited from the Pact for Research and Innovation, which

\section{GERMAN RESEARCH CENTRES}

\section{Health considerations}

One of the first issues facing the next government will be streamlining healthresearch facilities. Currently a patchwork of locally and nationally funded centres, the network is crying out for more coherence.

Since 2009, six national health-research centres have been created, including the German Center for Neurodegenerative Dieseases (DZNE) in Bonn. But the federal government is also, for example, injecting some $€ 300$ million (US $\$ 400$ million) into the Berlin Institute of Health, a hybrid body that unifies local health research at different sites in the city and also receives local state funds.

There are two options to smooth out such anomalies: turn the national centres into a German version of the US National Institutes of Health, or build up networks of local health institutes.

The government will therefore need to decide whether to focus on "localized cathedrals, like the Berlin Institute of Health, or creating more national institutes", says Pierluigi Nicotera, head of the DZNE. they jointly negotiated with the two previous governments to give institutions financialplanning security. Each organization received $3 \%$ annual budget rises between 2005 and 2008 , and $5 \%$ annual increases since. And the science ministry is contributing $€ 3.4$ billion to the Excellence Initiative for universities, a $€ 4$.6-billion government scheme that has been used to set up graduate schools and research collaborations (see Nature 487, 519-521; 2012).

For the DFG, the boom has had mixed effects. Despite its bigger coffers, the success rate of applications for individual DFG grants dropped from $47 \%$ in 2009 to 32\% last year. This is in part because more scientists are applying for grants, and because grant size has increased. It means that some excellent proposals will not get funded, says DFG president Peter Strohschneider. He worries that the falling success rate could demotivate researchers.

But by and large, the mood is upbeat. German science has shed its narrow outlook over the past decade. At Max Planck institutes, almost $90 \%$ of postdocs, half of all postgraduate students and more than $40 \%$ of scientific directors recruited in the past decade came from abroad. And the society has created cutting-edge institutes in emerging fields. In Mühlheim, scientists are exploring ways to improve chemical energy conversion and energy storage. And ocean scientists are looking forward to the completion of a $€ 450$-million icebreaker that is to replace the ageing flagship of Germany's research fleet.

Not everything is rosy, however. The ruling coalition parties and the Social Democrats are in favour of continuing the Pact for Research and Innovation beyond its planned 2015 expiry, but this is by no means guaranteed. And the Excellence Initiative finishes in 2017, raising fears that thousands of scientists employed on fixed-term contracts might be rendered jobless.

Junior researchers are especially at risk. Despite Germany's strong research presence, the country "needs to improve the career development of young scientists - there is not enough tenure-track here", says Oliver Brüstle, a stemcell researcher at the University of Bonn. In Germany's federal system, universities fall under the governance of the 16 states. As student numbers continue to rise, many institutions, especially in the poorer states in the north and east, are suffering from relative underfunding. A proposed constitutional change that would have allowed the central government to fund universities directly, and boost salaries of lecturers and researchers, last year failed to win support among the states. All parties say that they will tackle the issue again after the elections.

"For all the money that has been injected into the system, universities cannot offer more-permanent positions if they don't know if the cash will keep flowing," says Horst Hippler, president of the German Rectors' Conference. "The next government must urgently remedy that matter - or else the boom will have been a bubble." -

\section{Additional reporting by Alison Abbott.}

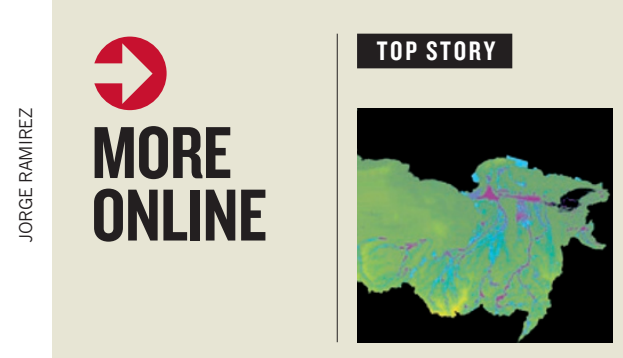

Ancient rivers cut migration routes through Sahara go.nature.com/ rknpqf

\section{MORE NEWS}

- Did a hyper-black hole spawn the Universe? go.nature.com/wtjfip - European Research Council funds arXiv go.nature.com/8xpkx7

- Ancient mantle plume left scar on North American continent go.nature.com/ ekrwe8

\section{VIDEO OF THE WEEK}

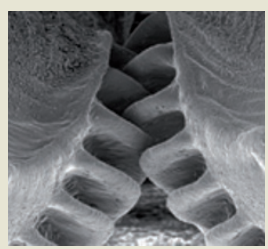

Leg cogs help insects to synchronize limbs for jumping go.nature. com/6gig5d 